Article

\title{
Directed Evolution of Clostridium thermocellum $\beta$-Glucosidase A Towards Enhanced Thermostability
}

\author{
Shahar Yoav ${ }^{1,2}$, Johanna Stern ${ }^{2}$, Orly Salama-Alber ${ }^{2}$, Felix Frolow ${ }^{3, \dagger}$, Michael Anbar ${ }^{2}$, \\ Alon Karpol ${ }^{4}$ D, Yitzhak Hadar ${ }^{1}$, Ely Morag ${ }^{2}$ and Edward A. Bayer ${ }^{2, *} \mathbb{D}$ \\ 1 Department of Plant Pathology and Microbiology, Robert H. Smith Faculty of Agriculture, Food and \\ Environment, the Advanced School for Environmental Studies, The Hebrew University of Jerusalem, \\ Rehovot 76100, Israel; shaharyoav@gmail.com (S.Y.); hadar@agri.huji.ac.il (Y.H.) \\ 2 Department of Biomolecular Sciences, The Weizmann Institute of Science, Rehovot 7610001, Israel; \\ jostern@rcip.co.il (J.S.); orlysala@gmail.com (O.S.-A.); michaelanbar@gmail.com (M.A.); \\ elymorag11@gmail.com (E.M.) \\ 3 Department of Molecular Microbiology and Biotechnology, Tel Aviv University, Tel Aviv 6997801, Israel; \\ hanbayer@gmail.com \\ 4 CelDezyner, 2 Bergman St, Tamar Science Park, Rehovot 7670504, Israel; alonkarpol@gmail.com \\ * Correspondence: ed.bayer@weizmann.ac.il; Tel.: +972-8-934-2373 \\ + Deceased, 29 August 2014.
}

Received: 4 September 2019; Accepted: 20 September 2019; Published: 23 September 2019

\begin{abstract}
Glucosidases are key enzymes in the process of cellulose utilization. It is the last enzyme in the cellulose hydrolysis chain, which converts cellobiose to glucose. Since cellobiose is known to have a feedback inhibitory effect on a variety of cellulases, $\beta$-glucosidase can prevent this inhibition by hydrolyzing cellobiose to non-inhibitory glucose. While the optimal temperature of the Clostridium thermocellum cellulosome is $70^{\circ} \mathrm{C}, \mathrm{C}$. thermocellum $\beta$-glucosidase $\mathrm{A}$ is almost inactive at such high temperatures. Thus, in the current study, a random mutagenesis directed evolutionary approach was conducted to produce a thermostable mutant with $\mathrm{K}_{\mathrm{cat}}$ and $\mathrm{K}_{\mathrm{m}}$, similar to those of the wild-type enzyme. The resultant mutant contained two mutations, A17S and $\mathrm{K} 268 \mathrm{~N}$, but only the former was found to affect thermostability, whereby the inflection temperature $\left(\mathrm{T}_{\mathrm{i}}\right)$ was increased by $6.4^{\circ} \mathrm{C}$. A17 is located near the central cavity of the native enzyme. Interestingly, multiple alignments revealed that position 17 is relatively conserved, whereby alanine is replaced only by serine. Upon the addition of the thermostable mutant to the $C$. thermocellum secretome for subsequent hydrolysis of microcrystalline cellulose at $70{ }^{\circ} \mathrm{C}$, a higher soluble glucose yield (243\%) was obtained compared to the activity of the secretome supplemented with the wild-type enzyme.
\end{abstract}

Keywords: Cellulase; random mutagenesis; cellulose degradation; structural analysis

\section{Introduction}

Cellulose, the major polymer in the plant cell wall, is the most abundant organic resource on Earth, and cellulosic is a primary feedstock for the production of ethanol-based biofuels. Cellulose is a highly crystalline homopolymer composed of individual chains of glucose, which form a planar structure, reinforced by inter and intra-chain hydrogen bond interactions [1]. Depending on the source, each chain contains from 100 to more than 10,000 glucose units, with the disaccharide cellobiose (composed of two glucose units oriented at $180^{\circ}$ along the chain axis) being its smallest repetitive unit [2]. In order to utilize cellulose as a resource for biofuel production, the chain must first be enzymatically hydrolyzed into its primary monomeric glucose units. The glucose is then used as a carbon source for alcoholic fermentation to produce bioethanol. Alternative fermentation processes 
can also be used for the production of various other biochemicals such as butanol, acetone, lactic acid, succinic acid and more. Thus, efficient enzymatic hydrolysis of the cellulose is crucial for increasing the cost-effectiveness of the bioethanol and biochemical production process [3,4].

In the plant cell wall, cellulose is encompassed by the hemicelluloses and lignin, which together create a chemically complex and recalcitrant structure $[5,6]$. The plant cell wall structure and the rigid nature of cellulose itself render the cellulose degradation process extremely difficult. For efficient degradation, a diverse set of plant cell wall-degrading enzymes is therefore required [7,8]. Cellulose hydrolysis is mediated by three major types of enzymes: endoglucanases, exoglucanases and $\beta$-glucosidases that work in synergy [9]. Endoglucanases can cleave the cellulosic chains in the middle, creating reducing and non-reducing ends. Exoglucanases hydrolyze the cellulosic chains from the newly formed chain ends in a "processive" (sequential) manner, leading to the formation of the soluble disaccharide cellobiose. Finally, $\beta$-glucosidases are capable of cleaving cellobiose into soluble glucose units. Cellobiose is known to serve as a strong feedback inhibitor (mainly for exoglucanases) [10], thus highlighting the significance of the $\beta$-glucosidases not only in providing the end product (glucose) but also in preventing feedback inhibition. For example, near-complete inhibition of the cellulosome of Clostridium thermocellum was observed at a concentration of only $2 \%$ cellobiose [11,12]. The addition of its native $\beta$-glucosidase A (BglA) was able to relieve inhibition, and thus to enhance the rate and degree of solubilization of crystalline cellulose $[13,14]$. The important role of BglA was also demonstrated by manipulating C. thermocellum 27405 to overexpress the BglA gene in vivo. The resultant strain demonstrated increased total cellulolytic activity during growth [15].

Extensive efforts have been made during the last decades for the development and assembly of efficient cellulolytic enzymatic cocktails. However, cellulose degradation is still not efficient enough to be cost effective $[3,16]$. One of the key bottlenecks for achieving cost-effective degradation of plant cell wall biomass is the requirement for large amounts of cellulases (about 100-200 $\mathrm{g}$ of cellulase per gallon of cellulosic ethanol) [17]. In this context, thermostable enzymes are gaining wide interest in the industry, since they are better suited for harsh process conditions, such as those used for the bioethanol production [18]. Thermostability of enzymes can be increased by genetic modification. Increasing the thermostability of an enzyme, while retaining its activity, is thought to enhance its overall performance, especially for the extended time periods necessary for degradation of cellulosic substrates $[19,20]$. Moreover, thermostable enzymes can be recycled more efficiently, thereby lowering overall production costs [21,22]. Finally, thermostable processes can reduce contamination [23]. Taken together, engineering thermostable enzymes is important to achieve the relatively low-cost biodegradation of biomass for the production of cellulosic ethanol [24]. Indeed, a wide range of bacterial or fungal cellulases was subjected to genetic modification to increase their thermostability [24-28].

C. thermocellum is a thermophilic bacterium, and its cellulosome is considered to be one of the most efficient natural systems for cellulose conversion [29]. Our group and others have previously reported the design of highly thermostable mutants derived from $C$. thermocellum cellulolytic enzymes, such as the endoglucanase Cel8A [30-32] and the exoglucanase Cel48S [33], which have proved to be stable at very high temperature ranges (around $80^{\circ} \mathrm{C}$ ). In nature, C. thermocellum utilizes cell-surface-bound cellulosomes to hydrolyze the cellulose into soluble cellobiose and other cellodextrins, which are then actively transported into the cells and hydrolyzed to glucose by periplasmic $\beta$-glucosidase $[10,34]$. The maximal cellulose degradation capacity mediated by the $C$. thermocellum cellulosome could be achieved at $70{ }^{\circ} \mathrm{C}$ [35]. However, the results reported here demonstrate inactivation of the recombinant C. thermocellum BglA (Clo1313_2020) at such high temperatures. Thus, and due to the important role of $\beta$-glucosidases, enhancing the thermostability of $C$. thermocellum $\mathrm{BglA}$ is of great significance and was the goal of the current study.

Directed evolution, which consists of random mutagenesis and high-throughput screening approaches, is a powerful technique which does not require prior functional, structural, or mechanistic knowledge. Only suitable and effective screening strategies for the desired activity are required [36,37]. The chromogenic product released from $p$-nitrophenyl- $\beta$-D-1,4-glucopyranoside ( $p$ NPG, an analogue 
of the natural substrate of $\beta$-glucosidase: cellobiose), enables efficient and rapid screening. Indeed, directed evolution methodologies have already been used in the past for enhanced thermostability of $\beta$-glucosidases from other (mostly mesophilic) organisms [36,38,39], which resulted in the creation of mutants stable at temperature ranges of $50-60{ }^{\circ} \mathrm{C}$ (the natural wild-type range of $\mathrm{C}$. thermocellum recombinant enzymes). In the current study, we used the directed evolution strategy based on the substrate analogue $p$ NPG, in order to create and reveal thermostable mutants of $C$. thermocellum $\mathrm{BglA}$. The functionality of this mutant was also validated under near-natural conditions, namely by examining the contribution of the thermostable BglA to the hydrolyses of microcrystalline cellulose by C. thermocellum cellulase mixtures.

\section{Results}

\subsection{Construction and Screening of C. Thermocellum BglA Clones Library}

In order to generate thermostable mutants of $C$. thermocellum BglA, in vitro directed evolution was applied on the full-length open reading frame (ORF) of the Clo1313_2020 gene. High numbers of mutation events per clone enable broad screening, but, in contrast, too many mutation events per clone might mask the desired mutation events. Here, a frequency leading to $\sim 20 \%$ active clones was chosen. Mutation frequency is determined by two parameters: the template amount and the number of polymerase reaction cycles. Hence, by using different template amounts and different thermal cycle numbers, appropriate mini-libraries were created. The amount of $100 \mathrm{ng}$ DNA template and 23 PCR thermal cycles led to $23 \%$ active colonies, which were used to create a library of $\sim 40,000$ clones. Sequencing eight active and non-active clones revealed an average of three and seven mutation events per active and non-active clones, respectively. In the next step, the library was screened for thermostable clones. About 8000 clones were screened, revealing 40 thermostable (red) clones.

\subsection{Characterization of the Thermostable Mutants}

In order to verify and quantify the thermostability of the detected clones, their residual activity after heat shock was calculated (residual activity was defined as the activity of the heat-shocked lysate $\times 100$ /activity of non-heated lysate). The residual activities of the two most thermostable clones were $149 \%$ and $140 \%$ higher than the wild type. The most thermostable clone was sequenced, revealing one silent mutation and two mutation events: A17S and K268N (herein referred to as Mut 1). The second thermostable clone revealed a single mutation event: S39T (referred here as Mut 2).

For further characterization, the two thermostable mutants and the wild-type BglA enzyme were recombinantly expressed in E. coli and purified. Purified enzymes were subjected to heat-shock treatment $\left(66-72{ }^{\circ} \mathrm{C}, 1 \mathrm{~h}\right)$ and residual activities were calculated (Figure 1). Indeed, both mutants were more thermostable than the wild-type enzyme, with Mut 1 being more thermostable than Mut 2. Mut 1 lost only $\sim 40 \%$ of its activity (residual activity $\sim 60 \%$ ) after heat-shock at $68.4{ }^{\circ} \mathrm{C}$. Under the same conditions, Mut 2 lost $~ 90 \%$ of its activity, and the wild-type BglA totally lost its activity. After heat-shock at $70{ }^{\circ} \mathrm{C}$, both the wild-type and Mut 2 enzymes totally lost their activity, while Mut 1 still exhibited residual activity of $\sim 9.5 \%$.

The kinetic parameters of the wild type and Mut 1 were measured (Table 1). Mut 1 revealed relatively similar and only slightly higher catalytic efficiency $\left(\mathrm{K}_{\mathrm{cat}} / \mathrm{K}_{\mathrm{m}}\right)$, with no statistical differences between the $\mathrm{K}_{\mathrm{cat}}$ and $\mathrm{K}_{\mathrm{m}}$ values compared to the wild type enzyme. The effect of each mutation event (namely A17S and K268N) on the thermostability of Mut 1 was examined. For this purpose, two recombinant enzymes were constructed and purified, one containing only the A17S mutation, and the other only $\mathrm{K} 268 \mathrm{~N}$. The enzymes were subjected to heat-shock $\left(66-72{ }^{\circ} \mathrm{C}, 1 \mathrm{~h}\right)$, and the residual activities were calculated (Figure 1). A17S demonstrated similar thermostability to Mut 1, indicating the major contribution of this substitution to the thermostability. In contrast, K268S did not demonstrate improvement in its thermostability (compared to that of the wild type), indicating that the improved thermostability derived only from the A17S mutation event. Using site-direct mutagenesis, A17 was 
substituted with other polar amino acids, namely, threonine, glutamine and asparagine. The resultant enzymes (A17T, A17Q and A17N) demonstrated much lower activity and thermostability, compared to the wild-type enzyme (Figure S1).

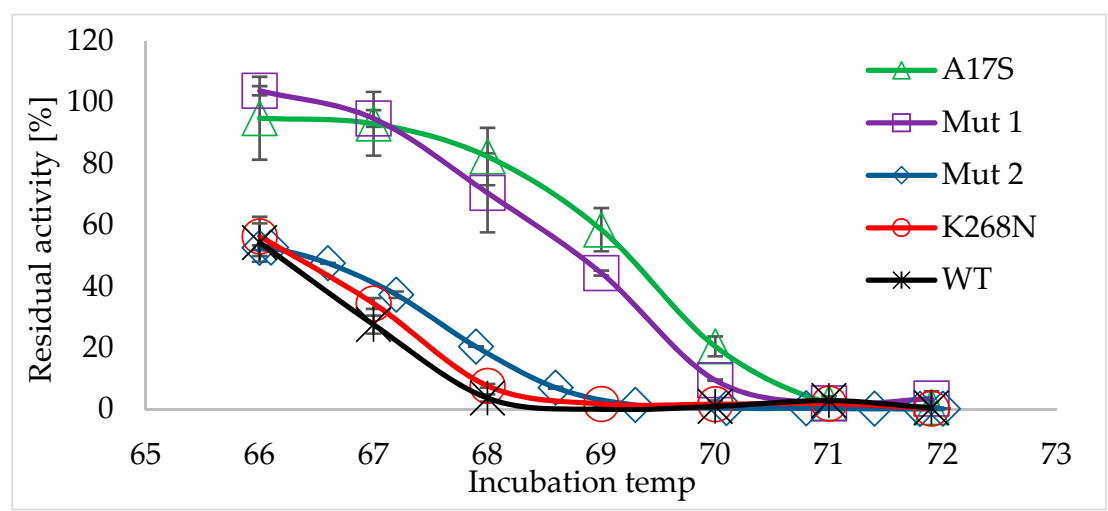

Figure 1. Thermostability of the various C. thermocellum BglA mutants. Wild-type (WT) C. thermocellum BglA and the different mutants were incubated at $66-72{ }^{\circ} \mathrm{C}$ for $1 \mathrm{~h}$, followed by activity assay (using $p$-nitrophenyl- $\beta$-D-1,4-glucopyranoside [ $p \mathrm{NPG}]$, an analogue of the natural $\beta$-glucosidase substrate). Residual activity of the different mutants (defined as the activity of the heat-shocked enzyme $\times 100$ /activity of the non-heated enzyme) was calculated. Mut 1 and A17S demonstrated similar thermostability.

Table 1. Kinetic parameters of $p$ NPG hydrolysis by wild-type C. thermocellum BglA and the thermostable mutant (Mut 1).

\begin{tabular}{ccc}
\hline Title & Wild Type & Mut 1 \\
\hline $\mathrm{V}_{\max }\left[\mathrm{M} \cdot \mathrm{s}^{-1}\right]$ & $9.92 \times 10^{-7} \pm 6.57 \times 10^{-8}$ & $9.1 \times 10^{-7} \pm 3.97 \times 10^{-8}$ \\
$\mathrm{~K}_{\mathrm{cat}}\left[\mathrm{s}^{-1}\right]$ & $76 \pm 5.036$ & $70 \pm 3.05$ \\
$\mathrm{~K}_{\mathrm{m}}[\mathrm{mM}]$ & $6.7 \pm 1.111$ & $5 \pm 0.59$ \\
$\mathrm{~K}_{\mathrm{cat}} / \mathrm{K}_{\mathrm{m}}\left[\mathrm{s}^{-1} \cdot \mathrm{M}^{-1}\right]$ & $11,282 \pm 900$ & $14,018 \pm 867$
\end{tabular}

Kinetic parameters of $C$. thermocellum BglA and Mut 1 were measured by $p$ NPG assay, and calculated by nonlinear fit by GraphPadPrism software.

The inflection temperatures $\left(\mathrm{T}_{\mathrm{i}}\right)$ of the wild-type, Mut 1 and A17S enzymes were measured using a NanoTemper Tycho NT.6 instrument. This assay is based on the changes in the intrinsic fluorescence from the aromatic amino acid residues tryptophan and tyrosine (measured at $350 \mathrm{~nm}$ and $330 \mathrm{~nm}$ ). During the assay, the temperature of the protein solution is ramped from $35^{\circ} \mathrm{C}$ to $95^{\circ} \mathrm{C}$ for a $3 \mathrm{~min}$ period, accompanied by continuous measurement of the fluorescence. Changes in the fluorescence signal indicate transitions in the folding state of a protein. The midpoint temperature at which a transition occurs is called the inflection temperature $\left(T_{i}\right)$ [40-42]. The $T_{i}$ of wild-type BglA, Mut 1 and A17S were $79.3 \pm 0.08,85.7 \pm 0.15$ and $85.7 \pm 0.16^{\circ} \mathrm{C}$, respectively, demonstrating an increase of $\sim 6.4^{\circ} \mathrm{C}$ in the $\mathrm{T}_{\mathrm{i}}$ (Figure 2). The effect of cellobiose (the natural substrate of $\beta$-glucosidases) added to the reaction mixture (at $1 \mathrm{mM})$ on the $\mathrm{T}_{\mathrm{i}}$ was also tested. The results were similar $\left(80 \pm 0.48^{\circ} \mathrm{C}\right.$, $85.9 \pm 0.53{ }^{\circ} \mathrm{C}$ and $85.8 \pm 0.1^{\circ} \mathrm{C}$ for the wild-type, Mut 1 and A17S, respectively), indicating no stability effect in the presence of cellobiose. 


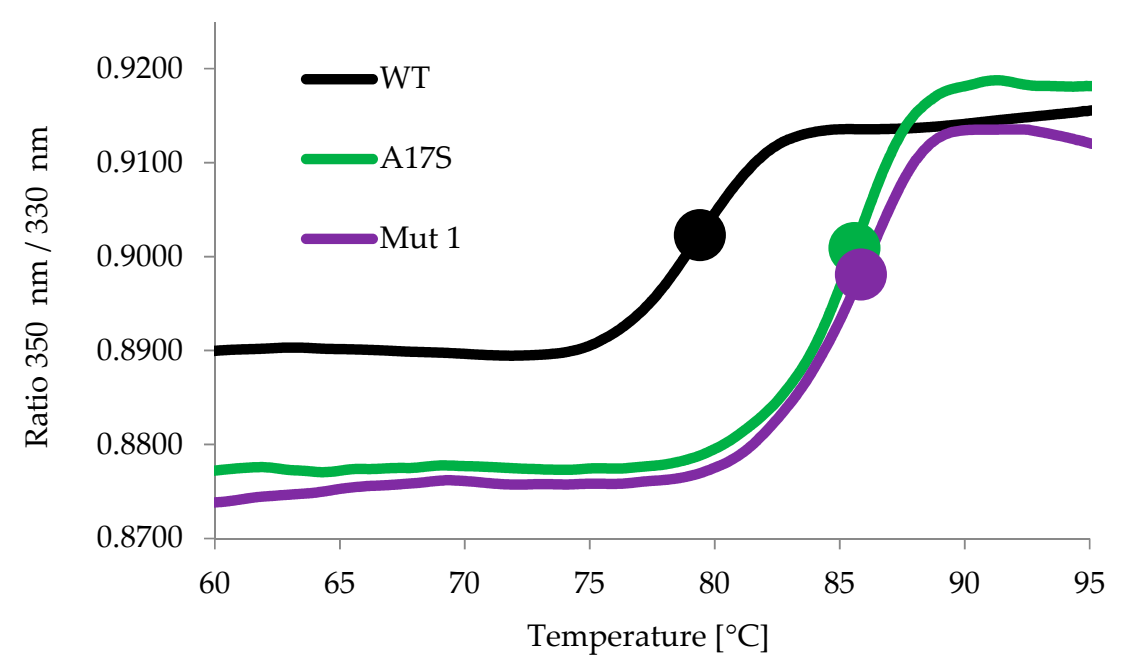

Figure 2. Inflection temperatures $\left(\mathrm{T}_{\mathrm{i}}\right.$ ) of wild-type (WT) C. thermocellum BglA, Mut 1 and A17S. The inflection temperatures were measured using a NanoTemper Tycho NT.6 instrument as described in the Methods section.

The amino acid sequence of $C$. thermocellum BglA was BLASTed against the NCBI nonredundant protein database. BLAST results for the residues adjacent to the A17S mutation event are represented schematically by the diagrams of amino acids frequencies in Figure 3. The residues near position 17 were found to be relatively conserved. Interestingly, the only amino acid replacing the alanine in position 17 in the different homologues was serine.

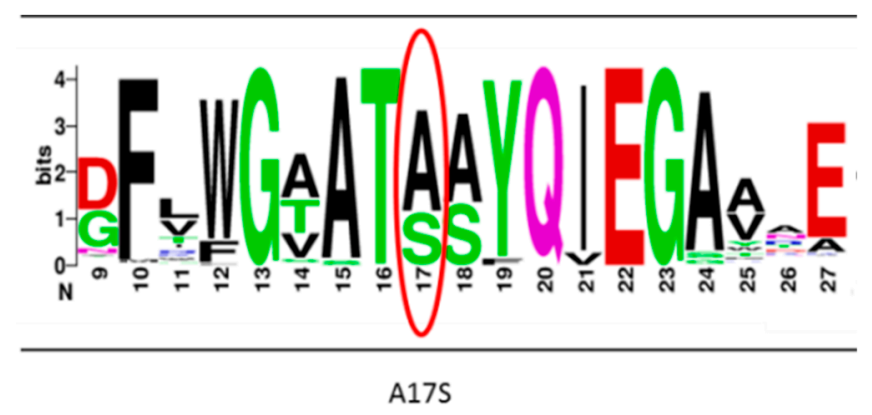

Figure 3. Amino acid frequencies in the residues surrounding the A17S mutation event. The relevant amino acid sequence of $C$. thermocellum BglA was BLASTed against the NCBI nonredundant protein database. The top 1000 hits were used to create the distribution scheme using WEBLOGO. Position 17 is marked by the red circle.

\subsection{Structural Aspects of BglA}

The crystal structure of wild-type $C$. thermocellum BglA was recently determined in our lab (PDB code 5OGZ, Table S1). BglA adopts the expected $(\beta / \alpha)_{8}$ TIM barrel fold, typically observed for clan-A $\beta$-glucosidases, with two active-site glutamates, Glu166 on strand $\beta 4$ and Glu355 on strand $\beta 7$, presumed to act as catalytic acid/base and nucleophile, respectively. Structure alignment of the Bg1A structure with those of four other family- $1 \beta$-glucosidases revealed that the glutamate residues are positioned very similarly with respect to the aligned structures. In addition, the distance between their C $\delta$ atoms is $5.33 \AA$, consistent with the properties of a retaining $\beta$-glycosidase. These highly conserved motifs are responsible for substrate binding and enzymatic hydrolysis of the glycosidic bond within the active site.

Figure $4 \mathrm{~A}$ shows the position of A17, which is located in a loop near the central cavity of the enzyme. The nearby coding region of K268, however, which is located in an outer $\alpha$-helix, was relatively non-conserved (data not shown). 

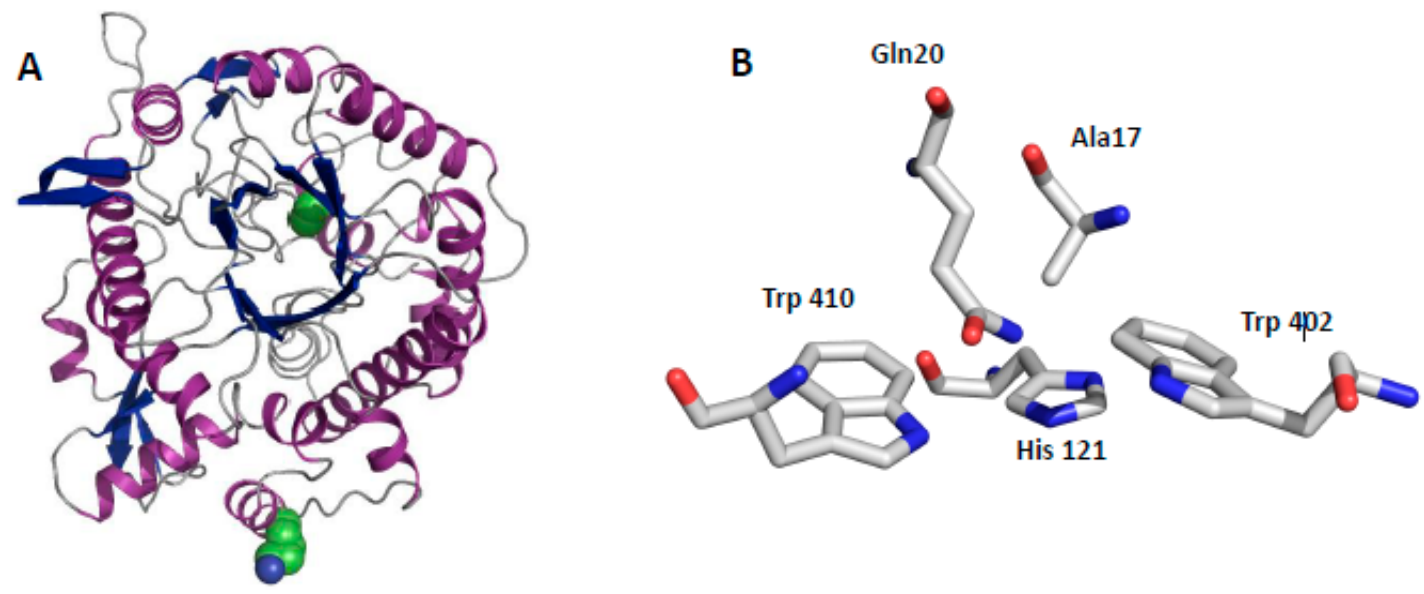

Figure 4. Structural analysis of $C$. thermocellum BglA. (A) Crystal structure of $C$. thermocellum BglA. $\alpha$-Helices are colored purple. $\beta$-sheets are colored blue. Ala17 and Lys268 (the two mutated positions in Mut 1) are displayed by spheres. (B) Ala17 and its adjacent residues. Carbon atoms are shown in white, oxygen atoms in red and nitrogen atoms in blue. Analysis was performed using PyMol software.

\subsection{Advantage of Thermostable BglA in the Cellulose Hydrolysis Process}

The contribution of thermostable BglA (Mut 1) to the cellulose hydrolysis process was examined. For this purpose, microcrystalline cellulose (Avicel) was hydrolyzed by the $C$. thermocellum secretome, supplemented with either Mut 1 or wild-type BglA at 60 and $70{ }^{\circ} \mathrm{C}$, and the concentration of the released soluble glucose was measured (Figure 5). Final glucose concentrations in the Mut 1 samples were higher than those of the wild-type samples at both temperatures. However, this advantage was much higher while working at $70{ }^{\circ} \mathrm{C}(57.4 \mathrm{mM}$ in Mut 1 versus $21.7 \mathrm{mM}$ in the wild-type samples), and lower while working at $60^{\circ} \mathrm{C}(47.1 \mathrm{mM}$ in Mut 1 versus $40.1 \mathrm{mM}$ in the wild-type).

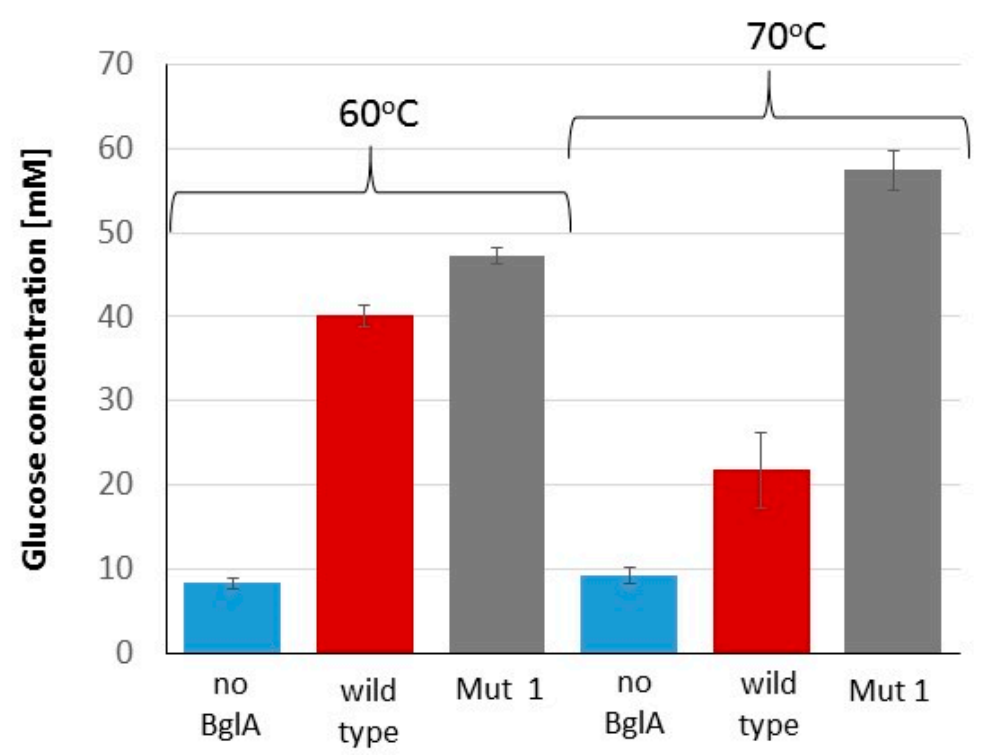

Figure 5. Hydrolysis of microcrystalline cellulose by the C. thermocellum secretome. Solutions containing the $\mathrm{C}$. thermocellum secretome were applied on Avicel with or without the addition of BglA (wild-type or mutant), followed by incubation at either 60 or $70{ }^{\circ} \mathrm{C}$ for $48 \mathrm{~h}$. The concentration of the released soluble glucose was measured by HPLC. Mut 1 showed higher glucose yields at both temperatures, with significant advantage at $70{ }^{\circ} \mathrm{C}$. The experiment was conducted in triplicate. Bars indicate standard deviation.

In addition, Mut 1 was integrated in our lab into a thermostable designer cellulosome [43]. To do so, a plasmid was created containing clone 1 attached to the gene segment coding for the dockerin 
module from Clostridium clariflavum. The expressed recombinant enzyme was successfully integrated into an artificial thermostable designer scaffoldin, which also contained appropriate dockerin-bearing thermostable Clostridium thermocellum mutants of both exoglucanase Cel48S and endoglucanase Cel8A. The resulting thermostable designer cellulosome exhibited a 1.7-fold enhancement in cellulose degradation (compared to the action of conventional designer cellulosomes that contain the respective wild-type enzymes). The results were published by Moraïs et al. in 2016 [43].

\section{Discussion}

Developing thermostable and highly active cellulase preparations is critical for achieving cost-effective enzymatic deconstruction of cellulosic biomass [24]. In this report, directed evolution was conducted on the $\beta$-glucosidase A gene of the thermophilic bacterium, $C$. thermocellum, to produce a potent thermostable mutant (Mut 1), which contained two mutations: Alanine at position 17 was substituted with serine, and lysine at position 258 was substituted with asparagine. However, only the A17S mutation was found to be responsible for the observed thermostability. The residues near position 17 were found to be conserved among the top 1000 homologous sequences of $C$. thermocellum $\beta$-glucosidase A. The observed conservation can indicate the important role of this position and on the importance of alanine 17 to the functionality of the enzyme [44,45]. The fact that serine was the only amino acid replacing alanine in position 17 in the different homologues is fully consistent with our results, in which the alanine-to-serine mutation produced a functional and thermostable mutant enzyme. Indeed, substitution of A17 with threonine, glutamine and asparagine resulted in almost inactive enzymes. According to Daniel et al. (1996), the enhanced stability of proteins can be achieved by an additional stabilizing force which is equivalent to only a few weak interactions $[31,46]$. Indeed, single mutation events were found to increase the thermostability of various cellulases [31,36,47]. In the case of $C$. thermocellum BglA, substitution of serine for alanine would likely result in hydrogen bonding with His 121 (Figure 4B), both of which are located near the active site. The newly created hydrogen bond would presumably help stabilize the enzyme. Our results also demonstrate that a single point mutation can increase the thermostability of the already naturally thermostable $C$. thermocellum BglA, thereby increasing its $\mathrm{T}_{\mathrm{i}}$ by $6.4^{\circ} \mathrm{C}$.

Mut 1 showed increased activity over the wild-type enzyme, with a much higher effect at $70{ }^{\circ} \mathrm{C}$ versus $60^{\circ} \mathrm{C}$ (the optimum growth temperature for $\mathrm{C}$. thermocellum). These results, together with the fact that Mut 1 has similar $\mathrm{K}_{\mathrm{cat}}$ and $\mathrm{K}_{\mathrm{m}}$, indicate that the mutation affects mainly the thermostability, rather than the activity of the enzyme. Directed evolution conducted on the mesophilic bacterium Paenibacillus polymyxa BglA revealed a more thermostable mutant containing the same A17S mutation event [36]. This mutation event increased the half-life of thermoinactivation by 11-fold, when applied at $50^{\circ} \mathrm{C}$. In addition, the authors obtained a lower $\mathrm{K}_{\mathrm{m}}$ and a higher $\mathrm{K}_{\text {cat }}$, resulting in doubling the catalytic efficiency. Considering the crystal structure of P. polymyxa BglA, a possible explanation for those effects was suggested [36]. The alanine at position 17 occurred in the internal cavity, buried among Gln20, His121, Trp398 and Trp406, near the active site. It was suggested that the alanine-to-serine substitution increased the residue volume, which in turn was assumed to be important for enzyme thermostability [48]. In addition, the proximity of the newly substituted polar residue (serine) to the above-mentioned amino acids, all of which participate in the ligand binding, was suggested to increase the binding affinity [49]. The crystal structure of $C$. thermocellum BglA revealed a similar structure (Figure 4B) to that of P. polymyxa BglA, with the Ala17 buried in the internal cavity among Gln20, His121, Trp402 and Trp410. Thus, a very similar mechanism may well be valid for $C$. thermocellum BglA although no significant effect on $\mathrm{K}_{\mathrm{m}}$ was measured.

Chromogenic substrates are often used for the screening of enzyme activity, since they enable rapid visual detection of the desired phenotype. However, improved hydrolysis of the synthetic chromogenic substrate does not necessarily correlate with that of the natural substrate of the enzyme [38,50,51]. Thus, a verification step of the enzymatic activity on the natural substrate is required following screening on 
substrate analogues. Thus, the contribution of Mut 1 to cellulose hydrolysis was tested in this study, thereby revealing its advantage at higher temperatures.

In nature, the assembly of the catalytic units of $C$. thermocellum into cellulosomes containing cellulose-binding modules (CBMs) resulted in the formation of higher local cellobiose concentrations at particular sites. However, $C$. thermocellum BglA does not possess a CBM module, and is not targeted towards the increased local cellobiose concentration. Instead, cellulosome-generated cellobiose is transported directly into the cell [34], and hydrolyzed to glucose by periplasmic $\beta$-glucosidases. In cell-free enzymatic systems, such as that reported here, removal of inhibitory cellobiose can be performed by adding BglA to the assay. Thus, targeting the recombinant BglA to the increased local cellobiose concentration might improve hydrolysis efficiency. In a former study conducted by our lab, we reported the design of a recombinant form of the wild-type $C$. thermocellum BglA, which possessed the ability to directly bind to the cellulosome via cohesin-dockerin interaction [52]. Integration of BglA into the $C$. thermocellum cellulosome led to higher degradation levels of microcrystalline cellulose and pretreated switchgrass, compared to cellulosomes supplemented with the soluble wild-type form of the enzyme. By using the same technique, the thermostable Mut 1 was incorporated into thermostable designer cellulosomes, which now demonstrated a 1.7-fold enhancement in cellulose degradation, compared to a non-thermostabilized designer cellulosome preparation [43]. These results further emphasize the advantage of thermostable mutants for improving lignocellulosic biomass conversion.

Several approaches can be applied to design thermostable cellulases. In the current study, the directed evolution approach was used for the improvement of $C$. thermocellum BglA. This strategy is based on random mutagenesis and sequential screening rather than a rational hypothesis-based approach. This powerful method does not require preliminary knowledge about the structure of the enzyme, and can reveal mutations that would not be revealed by knowledge-dependent approaches. However, in the future, the recently solved crystal structure of $C$. thermocellum BglA (Table S1) can be used for rational design, in order to further improve the thermostability and activity of Mut 1. [53].

Overall, the current study demonstrates that natural thermostable cellulases can be further improved. Exposing the "hidden" potential of plant cell wall-degrading enzymes is thus an important step towards cost-effective conversion of plant biomass into bioethanol or other biochemicals.

\section{Materials and Methods}

\subsection{Random Mutagenesis and Library Construction}

A library of $C$. thermocellum BglA mutant clones was created as previously described $[30,31]$ with minor modifications. Different quantities $(20,100 \mathrm{or} 400 \mathrm{ng}$ ) of the $C$. thermocellum BglA open reading frame Clo1313_2020, cloned in a pET28a plasmid, were used as a template for error prone PCR according to the manufacturer's instructions, using Gene-Morph II Random Mutagenesis Kit (Stratagene, La Jolla, CA, USA). Thermal cycling parameters were $95^{\circ} \mathrm{C}$ for $2 \mathrm{~min}$ followed by 18,23 or 27 cycles of $95^{\circ} \mathrm{C}$ for $1 \mathrm{~min}, 55^{\circ} \mathrm{C}$ for $45 \mathrm{~s}$ and $72{ }^{\circ} \mathrm{C}$ for $2 \mathrm{~min}$, followed by a final step of $72{ }^{\circ} \mathrm{C}$ for $10 \mathrm{~min}$. T7 promoter primer and T7 terminator primer were used for amplification. The resulting PCR products were applied on $0.75 \%$ agarose gel. Extracted bands were treated with DpnI and diluted 100 times. The solution was then used as a template for sequential PCR reaction using ReadyMix ${ }^{\mathrm{TM}}$ Taq PCR Reaction Mix (Sigma-Aldrich, Rehovot, Israel) with primers: CAGTCCATGGCAAAGATAAC (NcoI restriction site) and CACGCTCGAGGAAACCGTTGTTTTTGATTAC (XhoI restriction site). The thermal cycling parameters followed the manufacturer's instruction, with an annealing temperature of $55^{\circ} \mathrm{C}$ and elongation time of $2 \mathrm{~min}$. The amplified products were purified, restricted with NcoI and XhoI according to the manufacturer's instructions and ligated to the pET28a-based plasmid treated with NcoI/XhoI and shrimp alkaline phosphatase (SAP). The ligated plasmids were treated with SacI in order to remove unrestricted vector. (New England Biolabs, UK enzymes were used in the restriction and ligation process). Plasmids were then electrotransformed into E. coli XL1 electro-competent cells and purified using a miniprep kit (QIAprep Spin Miniprep Kit, Qiagen, Redwood City, CA, USA), 
creating minilibraries. The minilibraries were transformed into E. coli BL21 competent cells and plated on LB plates, containing $1.5 \%$ agar, $4 \mu \mathrm{M}$ isopropyl $\beta$-D-1-thiogalactopyranoside (IPTG) and $50 \mu \mathrm{g} / \mathrm{mL}$ kanamycin. The plates were incubated overnight at $37^{\circ} \mathrm{C}$. A solution of $25 \mathrm{mM}$ citrate buffer, $\mathrm{pH}=6.1$, containing $0.75 \%$ agar, was then boiled, cooled to $45^{\circ} \mathrm{C}$ and supplemented with Magenta GlcA (5-Bromo-6-chloro-3-indolyl $\beta$-D-glucuronide cyclohexylammonium salt, Sigma Aldrich) to a final concentration of $0.02 \%$, and applied onto the plates, creating an additional layer. The plates were dried for $1 \mathrm{~h}$ at room temperature and then incubated at $60{ }^{\circ} \mathrm{C}$ for $1.5 \mathrm{~h}$ (until red colonies appeared). The percentage of the red colonies was calculated and the parameters leading to $20-30 \%$ active clones were further used to increase library.

\subsection{Screening for Thermostable Clones}

Library screening was performed as detailed in the previous section with two additional steps: Plasmids were transformed into E. coli BL21 competent cells and plated on LB plates containing 1.5\% agar, $4 \mu \mathrm{M}$ IPTG and $50 \mu \mathrm{g} / \mathrm{mL}$ kanamycin. The plates were incubated overnight at $37^{\circ} \mathrm{C}$. They were then replicated on fresh LB agar plates using silk snippets, heat-shocked at $70^{\circ} \mathrm{C}$ for $50 \mathrm{~min}$ and cooled at $4{ }^{\circ} \mathrm{C}$. A layer of $25 \mathrm{mM}$ citrate buffer, $\mathrm{pH} 6.1,0.75 \%$ agar and $0.02 \%$ Magenta GlcA, was added to the plates (as detailed above), which were dried for $1 \mathrm{~h}$ at room temperature and then incubated at $60^{\circ} \mathrm{C}$ for $1.5 \mathrm{~h}$. The replicates were used to purify the plasmids of selected red colonies, and selected clones were sequenced. A plate containing wild-type C. thermocellum BglA was used as a control.

\subsection{Residual Activity of Overexpressing BglA Colonies}

Colonies overexpressing thermostable mutants (as indicated by the appearance of red color) were grown on liquid LB medium $(0.5 \mathrm{~mL})$, containing $0.1 \mathrm{mM} \mathrm{IPTG}$ and $50 \mu \mathrm{g} / \mathrm{mL}$ kanamycin, overnight at $37^{\circ} \mathrm{C}$ in 96-deep-well plates. In order to extract the proteins, each well was supplemented with $20 \mu \mathrm{L}$ of Popculture (Novagene, Darmstadt, Germany), DNaseI and lysozyme, and the plate was incubated at $37^{\circ} \mathrm{C}$ for $20 \mathrm{~min}$. The lysate was diluted 30 times in $50 \mathrm{mM}$ citrate buffer, $\mathrm{pH}$ 6.1. Diluted lysate $(100 \mu \mathrm{L})$ was incubated at $66^{\circ} \mathrm{C}$ for $75 \mathrm{~min}$ and cooled on ice. Then, $15 \mu \mathrm{L}$ of heated and non-heated samples were added to $1 \mathrm{mM} p$-nitrophenyl- $\beta$-D-glucopyranoside ( $p N P G$, Sigma Aldrich, St. Louis, MO, USA) solution and incubated for $45 \mathrm{~min}$ at $60^{\circ} \mathrm{C}$. The reaction was terminated by adding $85 \mu \mathrm{l}$ of $1 \mathrm{M}$ carbonate buffer, $\mathrm{pH} 9.5$, and optical densities of the samples were measured at a wavelength of $405 \mathrm{~nm}$. Residual activity was calculated by comparing the activity of the heated versus non-heated samples.

\subsection{Protein Expression and Purification}

The resulting $C$. thermocellum BglA mutants and wild-type enzymes were produced by expression of relevant plasmids into E. coli BL21 (IDE3) pLysS cells. The proteins were extracted and purified on an Ni-nitrilotriacetic acid (NTA) column (Qiagen, Hilden, Germany), as reported earlier [30]. Purity of the recombinant proteins was assessed by SDS-PAGE on $12 \%$ acrylamide gels, and fractions, containing the pure recombinant protein, were pooled and concentrated using AmiconUltra $15 \mathrm{~mL}$ 50,000 MWCO concentrators (Millipore, Bedford, MA, USA). Protein concentration was estimated from the absorbance at $280 \mathrm{~nm}$, based on the known amino acid composition of the protein, using the Protparam tool (http://www.expasy.org/tools/protparam.html). Proteins were stored in $50 \%(v / v)$ glycerol at $-20^{\circ} \mathrm{C}$.

\subsection{Stability Assay}

Solutions of $50 \mathrm{mM}$ citrate buffer, $\mathrm{pH}$ 6, containing $7 \mu \mathrm{g} / \mathrm{mL}$ of the recombinant enzymes, were incubated at $66-72{ }^{\circ} \mathrm{C}$ for $1 \mathrm{~h}$ and then cooled on ice. Heated and non-heated samples were diluted to a final enzymatic concentration of $1.05 \mu \mathrm{g} / \mathrm{mL}$ in a solution of $50 \mathrm{mM}$ citrate buffer, $\mathrm{pH}$ 6.1, containing $1 \mathrm{mM} p$ NPG, incubated for $10 \mathrm{~min}$ at $60^{\circ} \mathrm{C}$, cooled on ice, and supplemented with equal amounts of $1 \mathrm{M}$ carbonate buffer, $\mathrm{pH}$ 9.5. Optical densities of the samples were measured at a wavelength of $405 \mathrm{~nm}$. Residual activity was calculated by comparing the activity of the heated versus non-heated enzymes. 


\subsection{Kinetic Parameters Measurements}

A solution of $50 \mathrm{mM}$ citrate buffer, $\mathrm{pH}$ 6.1, containing 0-25 mM $p \mathrm{NPG}$, was supplemented with a concentration of $13 \mathrm{nM}$ enzyme (wild-type or mutant) and incubated at $60{ }^{\circ} \mathrm{C}$ for $8 \mathrm{~min}$ in a preheated 96-well plate, accompanied by continued measurements at $\mathrm{OD}_{405}$. The concentrations of end product ( $p$-nitrophenol) were calculated using known concentrations of $p$-nitrophenol. Kinetic parameters were calculated by nonlinear fit using the GraphPadPrism software (GraphPad Software, Inc., San Diego, CA, USA)

\subsection{Sequence Analysis}

The protein sequence of $C$. thermocellum BglA (ADU75064.1) was BLASTed against the NCBI non-redundant protein database. The top 1000 hits with $E$-value $<0.001$ were further aligned. Frequency of amino acids was visualized using WEBLOGO version 2.8.2.

\subsection{Purification of the C. Thermocellum Secretome}

C. thermocellum DSM1313 was grown on GS-2 medium $\left(0.5 \mathrm{~g} / \mathrm{L} \mathrm{K}_{2} \mathrm{HPO}_{4}, 0.5 \mathrm{~g} / \mathrm{L} \mathrm{MgCl} 2 \cdot 6 \mathrm{H}_{2} \mathrm{O}\right.$, $0.5 \mathrm{~g} / \mathrm{L} \mathrm{KH} \mathrm{PO}_{4}, 1.3 \mathrm{~g} / \mathrm{L}\left(\mathrm{NH}_{4}\right)_{2} \mathrm{SO}_{4}, 0.002 \mathrm{~g} / \mathrm{L}$ resazurin, $10.5 \mathrm{~g} / \mathrm{L} \mathrm{MOPS}$ buffer, $5 \mathrm{~g} / \mathrm{L}$ yeast extract, $1.25 \mathrm{mg} / \mathrm{L}$ iron(II) sulfate and $0.5 \mathrm{mM} \mathrm{CaCl}_{2}$, adjusted with $10 \mathrm{M} \mathrm{NaOH}$ to a final $\mathrm{pH}$ of 7.2 ) with $0.5 \%$ microcrystalline cellulose (Avicel, Sigma Aldrich, St. Louis, MO, USA) in batch culture. Nitrogen flushing was used to achieve anaerobic conditions. After $48 \mathrm{~h}$ of incubation at $60{ }^{\circ} \mathrm{C}$, growth medium was centrifuged $(10,808 \times g, 10 \mathrm{~min})$. Soluble proteins were precipitate by $80 \%$ ammonium sulfate and re-suspended in Tris-buffered saline (TBS) buffer, pH 7.4. Protein concentration was measured by Bradford assay, using Bio-Rad protein assay solution (Bio-Rad) [54].

\subsection{Cellulose Hydrolysis Assay}

A quantity of $0.6 \mathrm{mg} / \mathrm{mL}$ of $C$. thermocellum secretome solution was applied to a suspension of $250 \mathrm{mg} / \mathrm{mL}$ of microcrystalline cellulose in $20 \mathrm{mM}$ citrate buffer, $\mathrm{pH}$ 6.1, with or without the addition of $2 \mu \mathrm{g} / \mathrm{mL} \mathrm{BglA} \mathrm{(wild-type} \mathrm{or} \mathrm{mutant)} \mathrm{in} \mathrm{a} \mathrm{reaction} \mathrm{volume} \mathrm{of} 2 \mathrm{~mL}$. Samples were incubated at 60 and $70^{\circ} \mathrm{C}$ for $48 \mathrm{~h}$, and centrifuged $(16,100 \times g, 5 \mathrm{~min})$. Released soluble sugars were analyzed by high-pressure liquid chromatography (HPLC, Agilent Infinity 1260 system, Agilent Technologies, Santa Clara, CA, USA) using an Aminex ${ }^{\circledR} \mathrm{HPX}-87 \mathrm{H}$ Ion Exclusion column (Bio-Rad, Hercules, CA, USA) with a guard column, mobile phase of $5 \mathrm{mM} \mathrm{H}_{2} \mathrm{SO}_{4}$ (flow-through of $0.6 \mathrm{~mL} / \mathrm{min}$ at $45^{\circ} \mathrm{C}$ ) in an Agilent 1260 Infinity LC system with RID detector (G1362A). Experiments were performed in triplicate.

\subsection{0. $T_{i}$ Measurements}

Recombinant BglA enzymes in TBSx1 buffer (with and without the addition of $1 \mathrm{mM}$ cellobiose) were used for $T_{i}$ measurements, using a NanoTemper Tycho NT.6 instrument Agentek (1987) Ltd., Tel Aviv, Israel), according to the manufacturer's instructions [42].

Supplementary Materials: Supplementary material can be found at http://www.mdpi.com/1422-0067/20/19/4701/ s1.

Author Contributions: S.Y., Y.H., E.M. and E.A.B. conceived and designed the experiments; S.Y. performed the experiments and analyzed the data, M.A. and A.K. supported and advised the kinetic-parameter measurements, directed evolution and the screening method; O.S.-A. and F.F. resolved the 3D structure, S.Y., Y.H., J.S. and E.A.B. wrote the paper.

Funding: This research was supported by the United States-Israel Binational Science Foundation (BSF grant No. 2013284), Jerusalem, Israel; the Israel Science Foundation (ISF grant no. 1349/13); the European Union NMP.2013.1.1-2: CellulosomePlus Project number 604530, and by a research grant from the Yotam Project via the Sustainability and Energy Research Initiative (SAERI) at the Weizmann Institute of Science.

Acknowledgments: The authors are pleased to acknowledge the advice and assistance of Yoav Barak, Department of Chemical Research Support, The Weizmann Institute of Science. We also thank Itamar Kass (Ben-Gurion 
University of the Negev, Beer Sheva, Israel and Amai Proteins, Ltd., Rehovot, Israel) and Oren Yaniv (Beckman Coulter, Rehovot, Israel) for their insight into the structural aspects of BglA.

Conflicts of Interest: The authors declare no conflict of interest.

\section{Abbreviations}

BglA $\beta$-glucosidase A

$p$ NPG $\quad p$-nitrophenyl- $\beta$-D-glucopyranoside

CBM cellulose binding module

\section{References}

1. Bayer, E.A.; Shoham, Y.; Lamed, R. Lignocellulose-decomposing bacteria and their enzyme system. In The Prokaryotes, 4th ed.; Rosenberg, E., Ed.; Springer: Berlin/Heidelberg, Germany, 2013; pp. 216-266.

2. Varrot, A.; Frandsen, T.P.; Von Ossowski, I.; Boyer, V.; Cottaz, S.; Driguez, H.; Schülein, M.; Davies, G.J. Structural Basis for Ligand Binding and Processivity in Cellobiohydrolase Cel6A from Humicola insolens. Structure 2003, 11, 855-864. [CrossRef]

3. Viikari, L.; Vehmaanperä, J.; Koivula, A. Lignocellulosic ethanol: from science to industry. Biomass Bioenergy 2012, 46, 13-24. [CrossRef]

4. Klein-Marcuschamer, D.; Oleskowicz-Popiel, P.; Simmons, B.A.; Blanch, H.W. The challenge of enzyme cost in the production of lignocellulosic biofuels. Biotechnol. Bioeng. 2012, 109, 1083-1087. [CrossRef] [PubMed]

5. Pettolino, F.A.; Walsh, C.; Fincher, G.B.; Bacic, A. Determining the polysaccharide composition of plant cell walls. Nat. Protoc. 2012, 7, 1590-1607. [CrossRef] [PubMed]

6. Pauly, M.; Keegstra, K. Cell-wall carbohydrates and their modification as a resource for biofuels. Plant J. 2008, 54, 559-568. [CrossRef] [PubMed]

7. Himmel, M.E.; Xu, Q.; Luo, Y.; Ding, S.-Y.; Lamed, R.; Bayer, E.A. Microbial enzyme systems for biomass conversion: emerging paradigms. Biofuels 2010, 1, 323-341. [CrossRef]

8. Lombard, V.; Ramulu, H.G.; Drula, E.; Coutinho, P.M.; Henrissat, B. The carbohydrate-active enzymes database ( CAZy ) in 2013. Nucleic Acids Res. 2014, 42, 490-495. [CrossRef] [PubMed]

9. Horn, S.J.; Vaaje-Kolstad, G.; Westereng, B.; Eijsink, V.G. Novel enzymes for the degradation of cellulose. Biotechnol. Biofuels 2012, 5, 45. [CrossRef]

10. Strobel, H.J. Growth of the thermophilic bacterium Clostridium thermocellum in continuous culture. Curr. Microbiol. 1995, 31, 210-214. [CrossRef]

11. Lamed, R.; Kenig, R.; Setter, E.; Bayer, E.A. Major characteristics of the cellulolytic system of Clostridium thermocellum coincide with those of the purified cellulosome. Enzyme Microb. Technol. 1985, 7, 37-41. [CrossRef]

12. Andrić, P.; Meyer, A.S.; Jensen, P.A.; Dam-Johansen, K. Effect and modeling of glucose inhibition and in situ glucose removal during enzymatic hydrolysis of pretreated wheat straw. Appl. Biochem. Biotechnol. 2010, 160, 280-297. [CrossRef] [PubMed]

13. Kadam, S.K.; Demain, A.L. Addition of cloned $\beta$-glucosidase enhances the degradation of crystalline cellulose by the Clostridium thermocellum cellulase complex. Biochem. Biophys. Res. Commun. 1989, 161, 706-711. [CrossRef]

14. Lamed, R.; Kenig, R.; Morgenstern, E.; Calzada, J.F.; De Micheo, F.; Bayer, E.A. Efficient cellulose solubilization by a combined cellulosome- $\beta$-glucosidase system. Appl. Biochem. Biotechnol. 1991, 27, 173-183. [CrossRef]

15. Maki, M.L.; Armstrong, L.; Leung, K.T.; Qin, W. Increased expression of $\beta$-glucosidase A in Clostridium thermocellum 27405 significantly increases cellulase activity. Bioengineered 2013, 4, 15-20. [CrossRef] [PubMed]

16. Mittal, A.; Decker, S.R. Special issue: Application of biotechnology for biofuels: transforming biomass to biofuels. 3 Biotech 2013, 3, 341-343. [CrossRef] [PubMed]

17. Zhang, Y.H.P.; Lynd, L.R. A functionally based model for hydrolysis of cellulose by fungal cellulase. Biotechnol. Bioeng. 2006, 94, 888-898. [CrossRef] [PubMed]

18. Heinzelman, P.; Snow, C.D.; Wu, I.; Nguyen, C.; Villalobos, A.; Govindarajan, S.; Minshull, J.; Arnold, F.H. A family of thermostable fungal cellulases created by structure-guided recombination. Proc. Natl. Acad. Sci. USA 2009, 106, 5610-5615. [CrossRef] [PubMed] 
19. Doi, R.H.; Kosugi, A. Cellulosomes: plant-cell-wall-degrading enzyme complexes. Nat. Rev. Microbiol. 2004, 2, 541-551. [CrossRef]

20. Blumer-Schuette, S.E.; Brown, S.D.; Sander, K.B.; Bayer, E.A.; Kataeva, I.; Zurawski, J.V.; Conway, J.M.; Adams, M.W.W.; Kelly, R.M. Thermophilic lignocellulose deconstruction. FEMS Microbiol. Rev. 2014, 38, 393-448. [CrossRef]

21. Cristina, A.; Felby, C.; Gama, M. Cellulase stability, adsorption/desorption profiles and recycling during successive cycles of hydrolysis and fermentation of wheat straw. Bioresour. Technol. 2014, 156, 163-169.

22. Skovgaard, P.A.; Jørgensen, H. Influence of high temperature and ethanol on thermostable lignocellulolytic enzymes. J. Ind. Microbiol. Biotechnol. 2013, 40, 447-456. [CrossRef] [PubMed]

23. Abdel-banat, B.M.A.; Hoshida, H.; Ano, A.; Nonklang, S.; Akada, R. High-temperature fermentation: How can processes for ethanol production at high temperatures become superior to the traditional process using mesophilic yeast? Appl. Microbiol. Biotechnol. 2010, 85, 861-867. [CrossRef] [PubMed]

24. Wu, I.; Arnold, F.H. Engineered thermostable fungal Cel6A and Cel7A cellobiohydrolases hydrolyze cellulose efficiently at elevated temperatures. Biotechnol. Bioeng. 2013, 110, 1874-1883. [CrossRef] [PubMed]

25. Nakazawa, H.; Okada, K.; Onodera, T.; Ogasawara, W.; Okada, H.; Morikawa, Y. Directed evolution of endoglucanase III (Cel12A) from Trichoderma reesei. Appl. Microbiol. Biotechnol. 2009, 83, 649-657. [CrossRef] [PubMed]

26. Liu, W.; Zhang, X.; Zhang, Z.; Zhang, Y.P. Engineering of Clostridium phytofermentans endoglucanase Cel5A for improved thermostability. Appl. Environ. Microbiol. 2010, 76, 4914-4917. [CrossRef] [PubMed]

27. Voutilainen, S.P.; Boer, H.; Alapuranen, M.; Jänis, J.; Vehmaanperä, J.; Koivula, A. Improving the thermostability and activity of Melanocarpus albomyces cellobiohydrolase Cel7B. Appl. Microbiol. Biotechnol. 2009, 83, 261-272. [CrossRef]

28. Trudeau, D.L.; Lee, T.M.; Arnold, F.H. Engineered thermostable fungal cellulases exhibit efficient synergistic cellulose hydrolysis at elevated temperatures. Biotechnol. Bioeng. 2014, 111, 2390-2397. [CrossRef]

29. Bayer, E.A.; Belaich, J.P.; Shoham, Y.; Lamed, R. The cellulosomes: multienzyme machines for degradation of plant cell wall polysaccharides. Annu. Rev. Microbiol. 2004, 58, 521-554. [CrossRef] [PubMed]

30. Anbar, M.; Gul, O.; Lamed, R.; Sezerman, U.O.; Bayer, E.A. Improved thermostability of Clostridium thermocellum endoglucanase Cel8A by using consensus-guided mutagenesis. Appl. Environ. Microbiol. 2012, 78, 3458-3464. [CrossRef]

31. Anbar, M.; Lamed, R.; Bayer, E.A. Thermostability enhancement of Clostridium thermocellum cellulosomal endoglucanase Cel8A by a single glycine substitution. ChemCatChem 2010, 2, 997-1003. [CrossRef]

32. Yi, Z.; Pei, X.; Wu, Z. Introduction of glycine and proline residues onto protein surface increases the thermostability of endoglucanase CelA from Clostridium thermocellum. Bioresour. Technol. 2011, 102, 3636-3638. [CrossRef] [PubMed]

33. Smith, M.A.; Rentmeister, A.; Snow, C.D.; Wu, T.; Farrow, M.F.; Mingardon, F.; Arnold, F.H. A diverse set of family 48 bacterial glycoside hydrolase cellulases created by structure-guided recombination. FEBS J. 2012, 279, 4453-4465. [CrossRef] [PubMed]

34. Nataf, Y.; Yaron, S.; Stahl, F.; Lamed, R.; Bayer, E.A.; Scheper, T.; Sonenshein, A.; Shoham, Y. Cellodextrin and laminaribiose ABC transporters in Clostridium thermocellum. J. Bacteriol. 2009, 191, 203-209. [CrossRef] [PubMed]

35. Xu, C.; Qin, Y.; Li, Y.; Ji, Y.; Huang, J.; Song, H.; Xu, J. Factors influencing cellulosome activity in Consolidated Bioprocessing of cellulosic ethanol. Bioresour. Technol. 2010, 101, 9560-9569. [CrossRef] [PubMed]

36. Liu, W.; Hong, J.; Bevan, D.R.; Zhang, Y.-H.P. Fast identification of thermostable beta-glucosidase mutants on cellobiose by a novel combinatorial selection/screening approach. Biotechnol. Bioeng. 2009, 103, 1087-1094. [CrossRef] [PubMed]

37. Cobb, R.E.; Sun, N.; Zhao, H. Directed evolution as a powerful synthetic biology tool. Methods 2013, 60, 81-90. [CrossRef] [PubMed]

38. McCarthy, J.K.; Uzelac, A.; Davis, D.F.; Eveleigh, D.E. Improved catalytic efficiency and active site modification of 1,4-beta-D-glucan glucohydrolase A from Thermotoga neapolitana by directed evolution. J. Biol. Chem. 2004, 279, 11495-11502. [CrossRef] [PubMed]

39. Arrizubieta, M.J. Increased thermal resistance and modification of the catalytic properties of a beta -glucosidase by random mutagenesis and in vitro recombination. J. Biol. Chem. 2000, 275, 28843-28848. [CrossRef] 
40. Sierla, M.; Hõrak, H.; Overmyer, K.; Waszczak, C.; Yarmolinsky, D.; Maierhofer, T.; Vainonen, J.P.; Salojärvi, J.; Denessiouk, K.; Laanemets, K.; et al. The Receptor-like Pseudokinase GHR1 Is Required for Stomatal Closure[OPEN]. Plant Cell 2018, 30, 2813-2837.

41. Nilsen, J.; Bern, M.; Sand, K.M.K.; Grevys, A.; Dalhus, B.; Sandlie, I.; Andersen, J.T. Human and mouse albumin bind their respective neonatal Fc receptors differently. Sci. Rep. 2018, 8, 14648. [CrossRef]

42. Mohamadi, M.; Tschammer, N.; Breitsprecher, D. Quick protein binding analysis by label-free thermal shift analysis on the Tycho NT. 6. Available online: https://www.accela.eu/files/produc (accessed on 20 August 2019).

43. Moraïs, S.; Stern, J.; Kahn, A.; Galanopoulou, A.P.; Yoav, S.; Shamshoum, M.; Smith, M.A.; Hatzinikolaou, D.G.; Arnold, F.H.; Bayer, E.A. Enhancement of cellulosome-mediated deconstruction of cellulose by improving enzyme thermostability. Biotechnol. Biofuels 2016, 9, 323. [CrossRef] [PubMed]

44. Rodina, A.; Godson, G.N. Role of conserved amino acids in the catalytic activity of Escherichia coli primase. J. Bacteriol. 2006, 188, 3614-3621. [CrossRef] [PubMed]

45. Dokholyan, N.V.; Mirny, L.A.; Shakhnovich, E.I. Understanding conserved amino acids in proteins. Physica 2002, 314, 600-606. [CrossRef]

46. Daniel, R.M.; Dines, M.; Petach, H.H. The denaturation and degradation of stable enzymes at high temperatures. Biochem. J. 1996, 317, 1-11. [CrossRef] [PubMed]

47. Heinzelman, P.; Snow, C.D.; Smith, M.A.; Yu, X.; Kannan, A.; Boulware, K.; Villalobos, A.; Govindarajan, S.; Minshull, J.; Arnold, F.H. SCHEMA Recombination of a Fungal Cellulase Uncovers a Single Mutation That Contributes Markedly to Stability*. J. Boil. Chem. 2009, 284, 26229-26233. [CrossRef]

48. Haney, P.J.; Badger, J.H.; Buldak, G.L.; Reich, C.I.; Woese, C.R.; Olsen, G.J. Thermal adaptation analyzed by comparison of protein sequences from mesophilic and extremely thermophilic Methanococcus species. Proc. Natl. Acad. Sci. USA 1999, 96, 3578-3583. [CrossRef]

49. Sanz-Aparicio, J.; Hermoso, J.A.; Martínez-Ripoll, M.; Lequerica, J.L.; Polaina, J. Crystal structure of beta-glucosidase A from Bacillus polymyxa: insights into the catalytic activity in family 1 glycosyl hydrolases. J. Mol. Biol. 1998, 275, 491-502. [CrossRef] [PubMed]

50. González-Candelas, L.; Aristoy, M.C.; Polaina, J.; Flors, A. Cloning and characterization of two genes from Bacillus polymyxa expressing beta-glucosidase activity in Escherichia coli. Appl. Environ. Microbiol. 1989, 55, 3173-3177. [PubMed]

51. Kaur, J.; Chadha, B.S.; Kumar, B.A.; Ghatora, S.K.; Saini, H.S. Purification and characterization of ß-glucosidase from Melanocarpus sp. MTCC 3922. Electron. J. Biotechnol. 2007, 10, 260-270. [CrossRef]

52. Gefen, G.; Anbar, M.; Morag, E.; Lamed, R.; Bayer, E.A. Enhanced cellulose degradation by targeted integration of a cohesin-fused $\beta$-glucosidase into the Clostridium thermocellum cellulosome. Proc. Natl. Acad. Sci. USA 2012, 109, 10298-10303. [CrossRef]

53. Anbar, M.; Bayer, E.A. Approaches for improving thermostability characteristics in cellulases. Methods Enzymol. 2012, 510, 261-271. [PubMed]

54. Bradford, M.M. A rapid and sensitive method for the quantitation of microgram quantities of protein utilizing the principle of protein-dye binding. Anal. Biochem. 1976, 72, 48-254. [CrossRef]

(C) 2019 by the authors. Licensee MDPI, Basel, Switzerland. This article is an open access article distributed under the terms and conditions of the Creative Commons Attribution (CC BY) license (http://creativecommons.org/licenses/by/4.0/). 